\title{
TESTING ALKALI-REACTIVITY OF SELECTED CONCRETE AGGREGATES
}

\author{
Zdzisława Owsiak \\ Dept of Civil and Environmental Engineering, Technical University of Kielce, \\ al. 1000-lecia P.P. 7, 25-314 Kielce, Poland \\ E-mail: owsiak@tu.kielce.pl \\ Received 25 Sept 2006; accepted 29 March 2007
}

\begin{abstract}
In the present paper, results of alkali reactivity tests for selected silica aggregates, both rapid and slow alkali reactive, with the use of ASTM procedures, have been presented. The tests have covered the determination of the aggregate silica content dissolved in a solution of sodium hydroxide; scale of the expansion of mortar and concrete bars with the silica aggregate and high-alkali cement; as well as scale of the expansion of the mortar bars stored in a sodium hydroxide solution at $80^{\circ} \mathrm{C}$. Exemplary photographs of the microstructure of alkali reaction products for the selected silica aggregates have also been presented. Summing up the results of standard methods of the aggregate testing, considering their alkali sensitivity, the method which tests the deformation of the concrete bars including the aggregate at issue and increased alkali content cement seems to be the most conclusive. However, the test duration up to 180 days is too short, particularly for defining the slow-reactive aggregates reactivity, such as, for example, granites or quartzites. A major diagnostic symptom which confirms the occurrence of the alkali-aggregate reaction is the presence of the reaction products (alkali silicate gel) in the concrete.
\end{abstract}

Keywords: alkali-silica reaction, test methods, SEM.

\section{Introduction}

The varying aggregate properties, in particular those related to the rate of the alkali reaction, make it necessary to apply standard testing methods and assessment criteria for the aggregate reactivity [1]. The aim of the present paper has been to estimate alkali reactivity of selected silica aggregates with the application of a variety of standard testing methods.

In the tests carried out, the ASTM methods have been used as the most complete as well as providing the starting points for developing testing methods by RILEM TC 106 [2]. The ASTM C 289 chemical test has been used [3], together with long-term methods of testing mortar expansion in compliance with the ASTM C 227 [4] and concrete expansion in compliance with the ASTM C 1293 [5], as well as the accelerated mortar test in compliance with the ASTM C 1260 [6]. Tests of mortar and concrete microstructure after the alkali-silica reaction have been conducted by means of scanning microscopy combined with X-ray analysis within the microsurface.

The present paper includes test results and alkali reactivity assessment of the selected silica aggregates, both rapid and slow alkali reactive. The results of silica dissolving in a sodium hydroxide solution have been compared, as well as scale of the expansion of the mortar and concrete bars with silica aggregate and high-alkali content cement, and scale of the expansion of the mortar bars stored in a sodium hydroxide solution at $80{ }^{\circ} \mathrm{C}$.
Exemplary photographs showing the products microstructure of the selected silica aggregates-alkali reaction have been presented.

\section{Properties of alkali-reactive silica aggregates}

It is generally acknowledged that alkali-reactive aggregates are divided into two types: rapid and slow alkalireactive. Initially, the term of alkali-reactive aggregates was applied to rapid reactive, porous and occasionally hydrated silica minerals, such as opal or chalcedony, as well as a variety of heterogenic rock types, including chert, flint or certain types of volcano glass, which could be extremely reactive even during standard field performance [7]. Currently, reactions with the aggregate obtained from well-crystallised, higher-density quartz rocks, such as greywackes, sandstones, clay-mica slates or metamorphic rocks, are observed in concrete. Despite the slow reaction course in case of aggregates containing these rocks, the reaction leads to delayed concrete expansion and destruction. Also micro-crystalline or imperfectly crystallised quartz (stressed quartz) may be the reason for alkali reactivity in similar slow alkali-reactive aggregates [8].

In recent years, many researchers have noted an increase of new types of rocks which are alkali-reactive in concrete. Dolar-Mantuani [9] has collected the information and presented a list of potentially reactive rocks. In case of potentially reactive aggregates, regard to the rock type as the only criterion is inadequate, in particular for assesing polycrystalline, slow-reactive rocks. French [1] also suggests that a complete description of potentially reactive rocks is required. In like manner, Jensen [10] 
claims that alkali reactivity of slow-expansive rocks may be estimated through a microstructure analysis and well known field observations, rather than basing on a list of rocks derived from the traditional classification.

\section{Applied methods of aggregate alkali reactivity testing}

Potential aggregate reactivity has been estimated by means of a quick chemical method in accordance with the ASTM C 289 [3]. In ground aggregate, the content of silica dissolved in a sodium hydroxide solution at $80^{\circ} \mathrm{C}$ was determined and the decrease in the solution alkalinity was measured. The interpretation of the test results is not univocal, but it is usually assumed that the potentially deleterious reaction will occur if test results are contained to the right of the borderline marked in the chart. The potentially deleterious aggregates, represented by the points above the dashed line, may be highly alkali-reactive, but their field performance demonstrates a relatively low expansion [11]. It is believed that this method may be not suitable for all aggregate types; nevertheless, it does provide an adequate indicator for certain aggregate types and continues to be used in some cases [12].

Mortar bar expansion tests have been conducted in accordance with the ASTM C 227 method. From the aggregate tested of recommended graining, bars are made with the use of cement containing over $0,8 \%$ of $\mathrm{Na}_{2} \mathrm{O}_{\mathrm{e}}$. The bars are stored over water at $38^{\circ} \mathrm{C}$, their expansion being thus accelerated, and displaying a tendency to be larger than at either higher or lower temperatures. The aggregate tested is reactive if expansion exceeds $0,1 \%$ after 6 months.

In order to reduce the duration of the mortar bars, expansion test, an accelerated method with the use of high temperature $\left(80^{\circ}\right)$ and the medium of the sodium hydroxide solution (the ASTM C1260 method) has been devised [6]. This method enables to detect the potential of the deleterious alkali-silica reaction in mortar bars within 16 days. Indirectly, it detects the capacity of the aggregates to be used in concrete for the internal deleterious expansion caused by the alkali-silica reaction progress.

The long-term test method included in the ASTM C 1293 [5] covers the determination of the aggregate capacity for the alkali-silica reaction which causes concrete expansion. For this method the aggregate reactivity is related to the expansion volume exceeding 0,04\%, measured after 180 days of concrete curing. The concrete composition assumes the influence of the cementcontained alkali on the aggregate under extreme conditions, at the content of $5,25 \mathrm{~kg}$ of $\mathrm{Na}_{2} \mathrm{O}_{\mathrm{e}}$ in $1 \mathrm{~m}^{3}$ of concrete. This method provides test results supplementary to those obtained by means of other methods. Table 1 summarises these test methods.

The tests of mortar and concrete microstructures after the alkali-silica reaction have been conducted by means of scanning microscopy combined with X-ray analysis within the microsurface.

\section{Experiments}

\subsection{Materials used in tests}

In the present work several types of silica aggregates have been used. One of these is a Middle-Devonian quartzitic sandstone. The main quartzite mineral is microcrystalline quartz, and the binding agent is the secondary quartz binder which surrounds and joins the quartz grains. Chalcedony grains are also to be found. The other aggregate was obtained from granite, whose main components are quartz, microcrystalline quartz, potassium feldspar, plagioclases and biotite. The aggregate obtained though the breaking up of hornstone, ie silified limestone, has also been used in tests. In this case,

Table 1. Test methods for alkali-aggregate reactions

\begin{tabular}{|c|c|c|c|c|}
\hline Method & Purpose & Test type & Test duration & Notes \\
\hline $\begin{array}{l}\text { ASTM C } 289 \text { poten- } \\
\text { tial aggregate reac- } \\
\text { tivity }\end{array}$ & $\begin{array}{l}\text { Determination of } \\
\text { potential silica ag- } \\
\text { gregate reactivity }\end{array}$ & $\begin{array}{l}\text { Aggregate sample } \\
\text { reacts with alkaline } \\
\text { solution at } 80{ }^{\circ} \mathrm{C}\end{array}$ & 24 hours & $\begin{array}{l}\text { Quantitative result; some ag- } \\
\text { gregates produce insignificant } \\
\text { expansion in spite of having a } \\
\text { high soluble silica content }\end{array}$ \\
\hline $\begin{array}{l}\text { ASTM C } 227 \text { poten- } \\
\text { tial reactivity of } \\
\text { cement-aggregate } \\
\text { combinations (mor- } \\
\text { tar bar test) }\end{array}$ & $\begin{array}{l}\text { Method determines } \\
\text { the sensitivity of } \\
\text { cement-aggregate } \\
\text { combinations to } \\
\text { expansion caused by } \\
\text { the alkali reaction }\end{array}$ & $\begin{array}{l}\text { Mortar bars are } \\
\text { cured over water at } \\
37,8{ }^{\circ} \mathrm{C} \text { and in a } \\
\text { high relative humid- } \\
\text { ity }\end{array}$ & $\begin{array}{l}\text { First measurement at } 14 \\
\text { days; subsequent meas- } \\
\text { urements at } 1,2,3,4,6 \text {, } \\
9 \text { and } 12 \text { months; then } \\
\text { every } 6 \text { months as nec- } \\
\text { essary }\end{array}$ & $\begin{array}{l}\text { This method may not produce } \\
\text { significant expansion, particu- } \\
\text { larly in carbonate aggregates }\end{array}$ \\
\hline $\begin{array}{l}\text { ASTM C } 1260 \text { test- } \\
\text { ing the potential } \\
\text { aggregate } \\
\text { alkali-reactivity }\end{array}$ & $\begin{array}{l}\text { Potential of the } \\
\text { deleterious cement- } \\
\text { aggregate reaction } \\
\text { in mortar bars }\end{array}$ & $\begin{array}{l}\text { Mortar bars are } \\
\text { immersed in sodium } \\
\text { hydroxide solution } \\
\text { at } 80^{\circ} \mathrm{C}\end{array}$ & 16 days & $\begin{array}{l}\text { Good method for testing slow } \\
\text { reactive aggregates }\end{array}$ \\
\hline $\begin{array}{l}\text { ASTM C } 1293 \text { de- } \\
\text { termination of con- } \\
\text { crete bar length } \\
\text { change caused by the } \\
\text { alkali-silica reaction } \\
\text { (concrete bar test) }\end{array}$ & $\begin{array}{l}\text { Determination of the } \\
\text { potential expansion } \\
\text { caused by the alkali- } \\
\text { silica reaction for } \\
\text { cement-aggregate } \\
\text { combination }\end{array}$ & $\begin{array}{l}\text { Concrete bars are } \\
\text { cured over water, at } \\
38^{\circ} \mathrm{C}\end{array}$ & $\begin{array}{l}\text { First measurement at } 7 \\
\text { days; subsequent meas- } \\
\text { urements at } 28 \text { and } 56 \\
\text { days; then at } 3,6,9 \text { and } \\
12 \text { months; next every } 6 \\
\text { months as necessary }\end{array}$ & $\begin{array}{l}\text { Long test duration required; } \\
\text { method supplementary to } \\
\text { ASTM C 227, ASTM C } 289 \\
\text { and ASTM C } 1260\end{array}$ \\
\hline
\end{tabular}


Table 2. Mineral composition of cements and contents of sodium and potassium oxides [\%]

\begin{tabular}{c|c|c|c}
\hline \multirow{2}{*}{ Component } & \multicolumn{3}{|c}{ Cement samples } \\
\cline { 2 - 4 } & $\mathrm{A}$ & $\mathrm{B}$ & $\mathrm{C}$ \\
\hline $\mathrm{C}_{3} \mathrm{~S}$ & 58,4 & 52,0 & 56,9 \\
$\beta \mathrm{C}_{2} \mathrm{~S}$ & 16,9 & 23,8 & 16,1 \\
$\mathrm{C}_{3} \mathrm{~A}$ & 2,1 & 7,2 & 12,0 \\
$\mathrm{C}_{4} \mathrm{AF}$ & 17,0 & 11,0 & 9,1 \\
$\mathrm{C}_{2} \overline{\mathrm{S}} \mathrm{H}_{2}$ & 5,4 & 5,6 & 5,6 \\
\hline $\mathrm{Na}_{2} \mathrm{O}$ & 0,26 & 0,19 & 0,25 \\
$\mathrm{~K}_{2} \mathrm{O}$ & 0,52 & 1,08 & 1,44 \\
\hline $\mathrm{Na}_{2} \mathrm{O}_{\mathrm{e}}$ & 0,6 & 0,9 & 1,2 \\
\hline
\end{tabular}

the silica saturates limestone layers or creates lenticular forms of silification, and - occasionally - hornstone forms. Quartz occurs in them in the form of dovetailing grains or chalcedony spherulites with irregular or streaky textures. As a model alkali-reactive aggregate, quartz sand with opal addition of $4 \%$ weight has been used.

In the research work with the ASTM C 227 and ASTM C 1260 methods three Portland cements CEM I obtained by grinding of industrial clinkers to surface of $370 \mathrm{~m}^{2} / \mathrm{kg}$ have been used. An increase in the alkalies content has been obtained by the addition of $\mathrm{K}_{2} \mathrm{SO}_{4}$ to each cement on condition that total $\mathrm{SO}_{3}$ content in the cements was 3,0\%. In the ASTM C 1293 method a cement marked with „B” has been used and increase in the alkalies content has been obtained by the addition of $\mathrm{NaOH}$. The clinkers mineralogical composition and sodium and potassium contents in cements are presented in Table 2 included in the enclosure.

\subsection{Results of alkali reactivity tests}

Results of the alkali reactivity tests for quartzite and granite aggregates, hornstone and quartz sand with opal have been shown in Figs 1-4.

Measurements of aggregate solubility in a sodium hydroxide solution have been presented in Fig 1; measurements of the mortar expansion - in Fig 2; Fig 3 shows results of the mortar expansion tested by means of the accelerated method; and Fig 4 - results of the concrete expansion.

Comparative mortar test results obtained by means of the ASTM C 227 method and the accelerated method in accordance with the ASTM C 1260 have been presented in Fig 5.

The results obtained by means of the chemical method in accordance with the ASTM C 289 place opal and granite in the field of potentially reactive aggregate, while the results for quartzite and hornstone demonstrate that these are irreactive aggregates (Fig 1). This result is not unambiguous and cannot be a criterion for approval or rejection of an aggregate to be used in concrete. The problem related to aggregate assessment on the basis of a chemical test can result from the methodology of the soluble silica $\left(S_{c}\right)$ determination as other calcium ions present in the solution may cause a misassessment of the soluble silica content as well as they can affect the solution's alkalinity $\left(R_{c}\right)$.

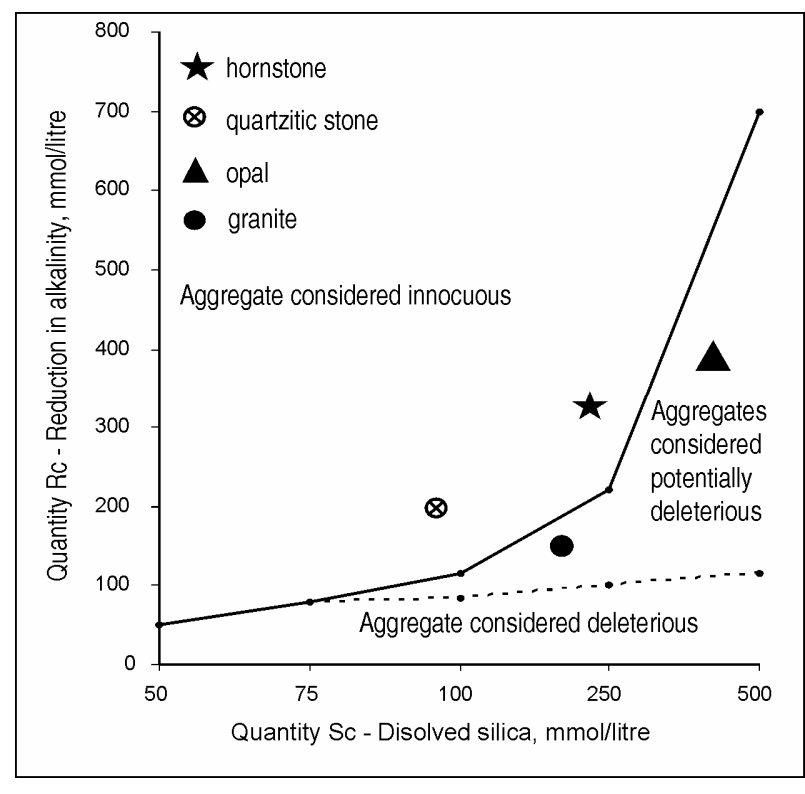

Fig 1. Illustration of division between innocuous and potentially deleterious aggregates on the basis of reduction in alkalinity test (ASTM C 289)

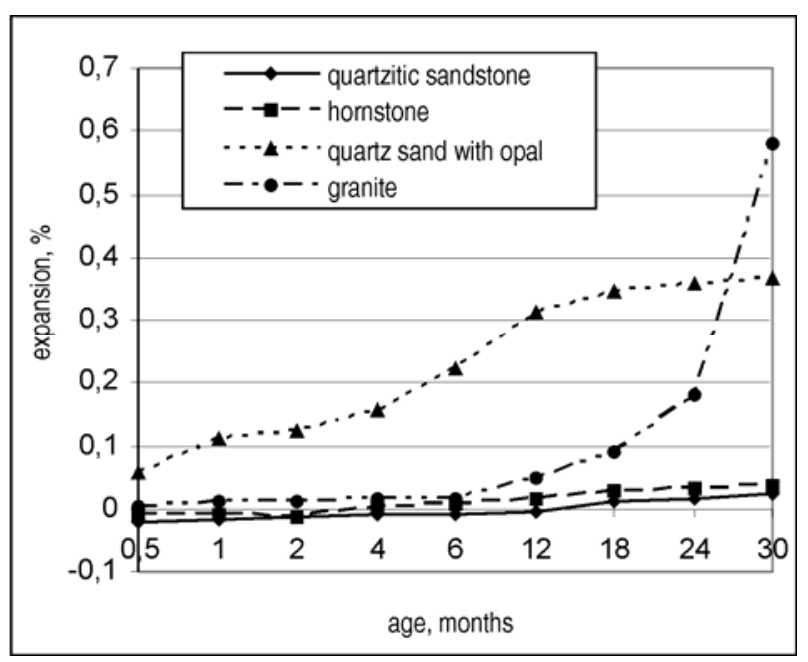

Fig 2. Expansion of mortar bars containing quartzitic sandstone, hornstone, quartz sand with opal and granite aggregate (ASTM C 227 method) 
Following the criterion of borderline expansion for a reactive aggregate amounting to at least $0,1 \%$ after 180 days, scale of the expansion of mortar bars with opalcontaining quartz sand only has shown that it is a reactive aggregate. However, the bars with the remaining three aggregate types: quartzite, hornstone and granite have not shown expansion which would testify to aggregate alkali reactivity (Fig 2) during the test of up to 180 days. Mortar bars with a granite aggregate demonstrated expansion exceeding $0,1 \%$ only after 21 months and in the further test period this expansion still increased and the samples developed cracks and fractures [13].

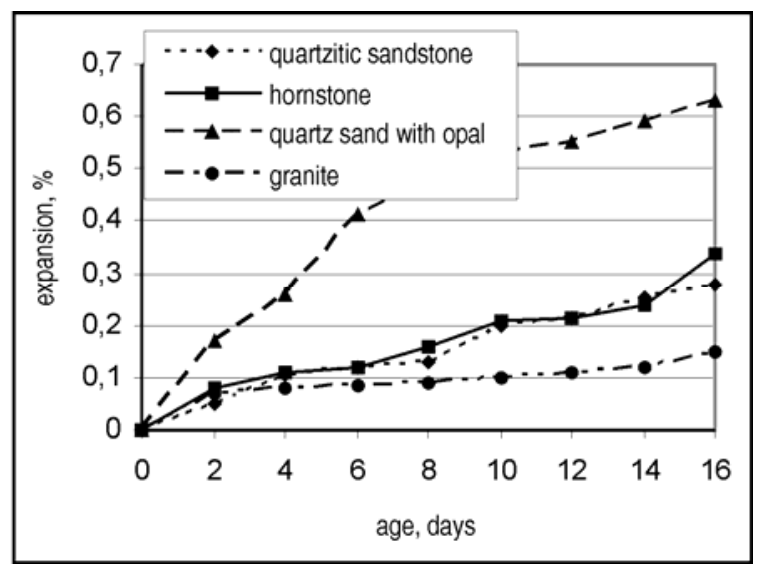

Fig 3. Expansion of mortar bars containing quartzitic sandstone, hornstone, quartz sand with opal and granite aggregate (ASTM C 1260 test)

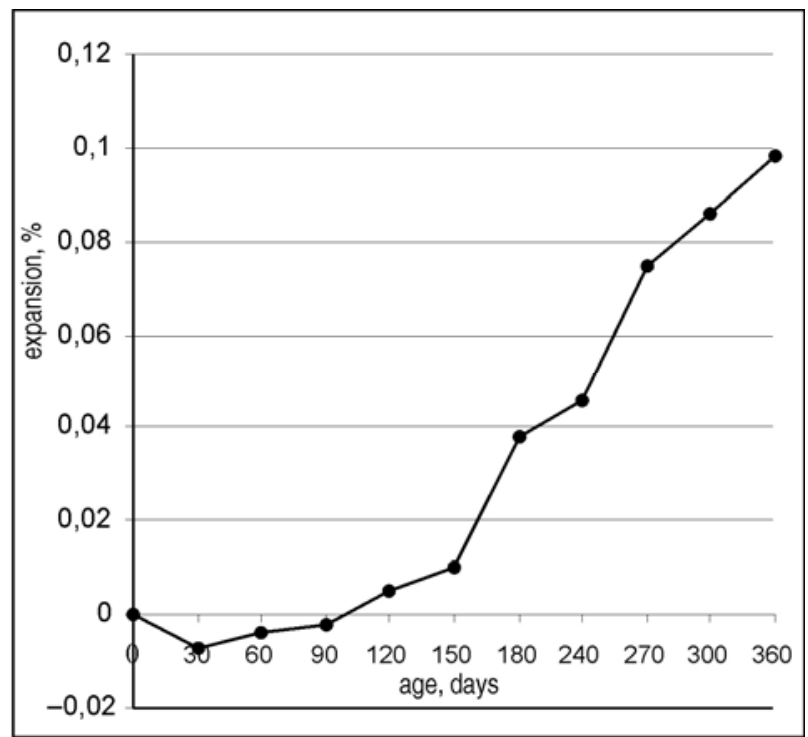

Fig 4. Expansion of concrete prism with quartzitic sandstone in the ASTM C 1293 test

In contrast, the results of the accelerated expansion test of the mortar bars with the aggregates tested (mortar bars stored in $\mathrm{NaOH}$ solution at $80{ }^{\circ} \mathrm{C}$ ) have shown, in all cases, expansion exceeding $0,1 \%$ after 16 testing days (Fig 3), which remains in compliance with the reactive/non-reactive criterion; all aggregates tested have demonstrated alkali reactivity. The accelerated method has been very popular recently, and in many cases the aggregate potential reactivity determined by means of the accelerated method is confirmed by field performance.

Similarly, the expansion of mortar bars with quartzite sandstone, measured in compliance with the ASTM C 1293, clearly suggests the occurrence of the alkalisilica reaction in concrete (Fig 4). After 180 days the measured expansion volume amounted to $0,04 \%$ and continued to grow rapidly after subsequent measurement periods. These results classify the quartzite sandstone aggregate tested as a clearly alkali reactive aggregate.

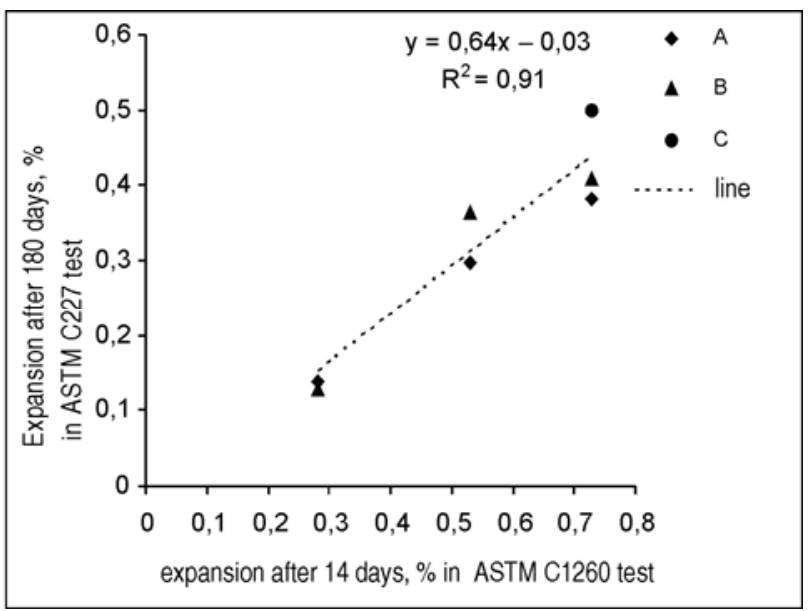

Fig 5. Comparison of the results of ASTM C 227 test and ASTM C 1260 method. A - cement with $0,6 \% \mathrm{Na}_{2} \mathrm{O}_{\mathrm{e}}$, B - cement with $0,9 \% \mathrm{Na}_{2} \mathrm{O}_{\mathrm{e}}, \mathrm{C}$ - cement with $1,2 \%$ $\mathrm{Na}_{2} \mathrm{O}_{\mathrm{e}}$

The final expansion (Fig 5) of the mortar bars containing a reactive silica aggregate (quartz sand with opal) tested with the accelerated method (ASTM C 1260) shows a good correlation with the test results of the mortar bars expansion (ASTM C 227). In the [14] paper one has also obtained a good correlation between concrete expansion determined according to the ASTM C 1293 (after 180 days) and mortar expansion in the accelerated method (ASTM C 1260) after 14 days.

The accelerated method can be used for quality control of the alkali reactive aggregates, making it possible to predict the expansion of the concrete basing on the maximum concrete expansion, obtained after 14 days.

While analysing the test results obtained, and taking the views quoted in [15-17] into account, one can claim that the chemical method and the long-term method of the mortar bar testing may underestimate alkali reactivity of a slow reactive aggregate. More reliable in their assessment of aggregate reactivity are expansion measurements of mortar stored in a sodium hydroxide solution, as well as expansion of the concrete bars with an extremely high alkali content $\left(5,25 \mathrm{~kg}\right.$ of $\mathrm{Na}_{2} \mathrm{O}_{\mathrm{e}}$ in $1 \mathrm{~m}^{3}$ of concrete). This conclusion finds confirmation in the occurrence of the alkali-silica reaction in concrete structures after a long period of use [18]. 


\subsection{Microstructural analysis}

The photographs showing the microstructure of mortars with an alkali reactive aggregate have been shown in Figs 6-9.

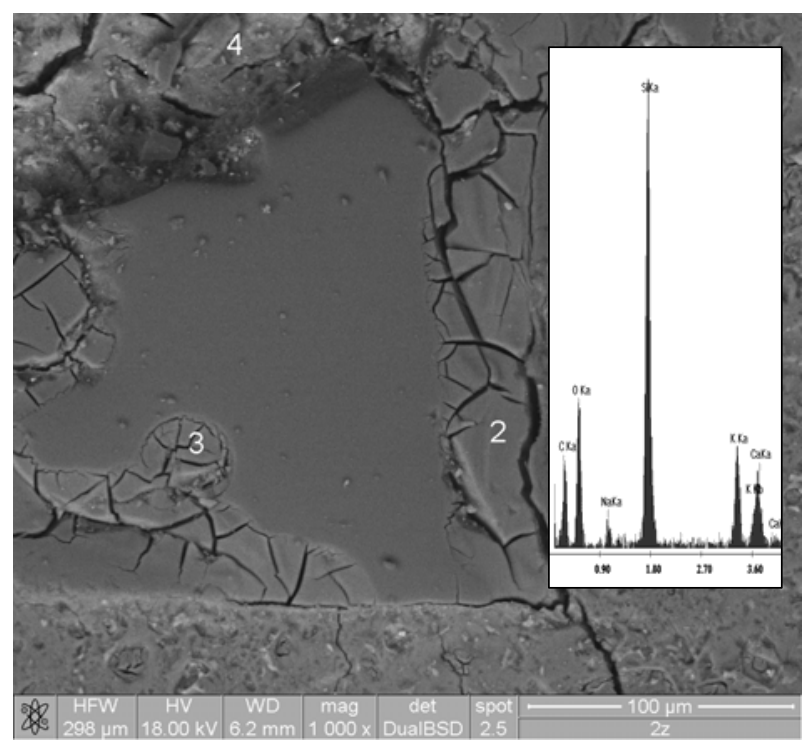

Fig 6. SEM image of potassium-sodium-calcium silica gel in the interface of opal grain

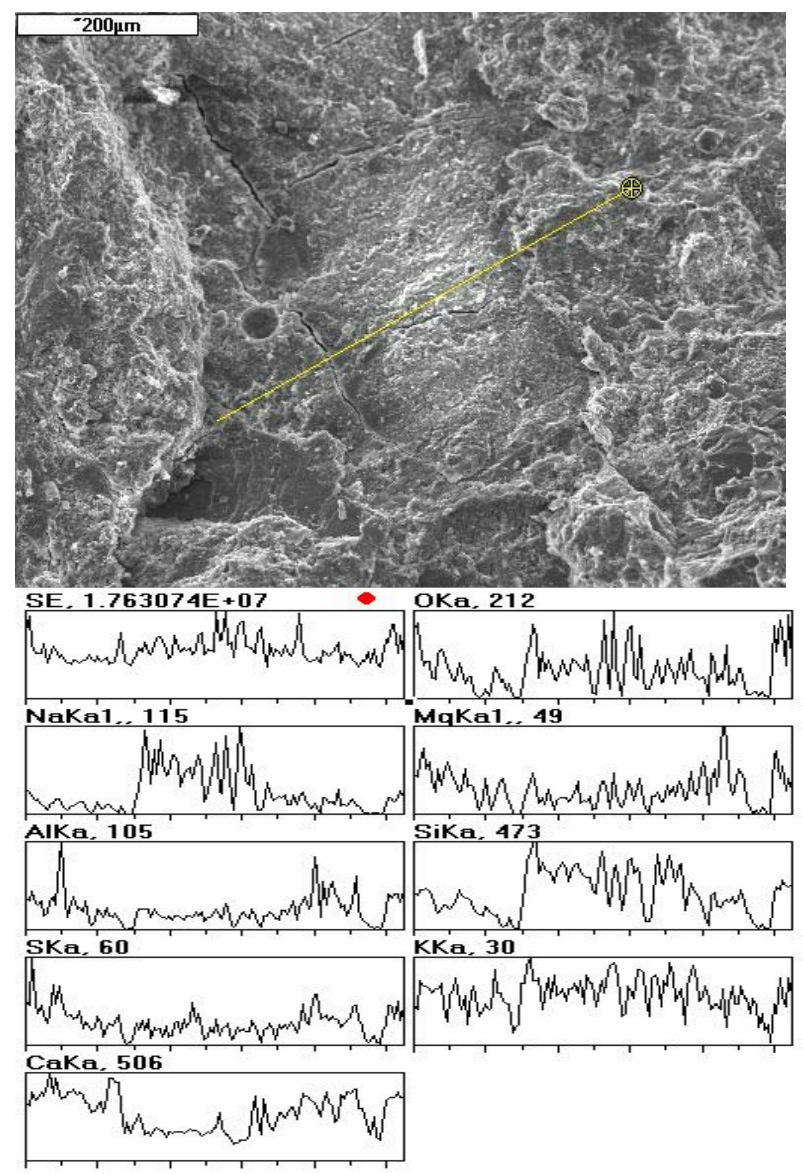

Fig 7. SEM image of reaction product in a mortar with hornstone aggregate and line profile of $\mathrm{Ca}, \mathrm{Si}, \mathrm{Na}, \mathrm{K}, \mathrm{S}$, obtained by microanalysis
Rapid alkali reactive aggregates, such as opal, can react through dissolving and forming the alkali silicate gel both next to the reactive grain's surface (Fig 6) and inside it. The reaction occurs in the zones or combinations with the aggregate, thus causing the appearance of microcracks, dissolving some silica grains, and forming the gel.

For slow reactive aggregates (Fig 7), the reaction is likely to start from the output cracks, non-uniformities or grain combinations, which provide a route for the alkaline pore solution. A certain part of reactive grains only may be capable of the alkali reaction. Despite the fact that a small amount of gel is produced, it may cause the separation of the combined grains, expansion and aggregate cracking. The appearing cracks seem to be more noticeable, longer and with clearly defined borders. These cracks may be more sensitive to stress during a concrete structure operating.

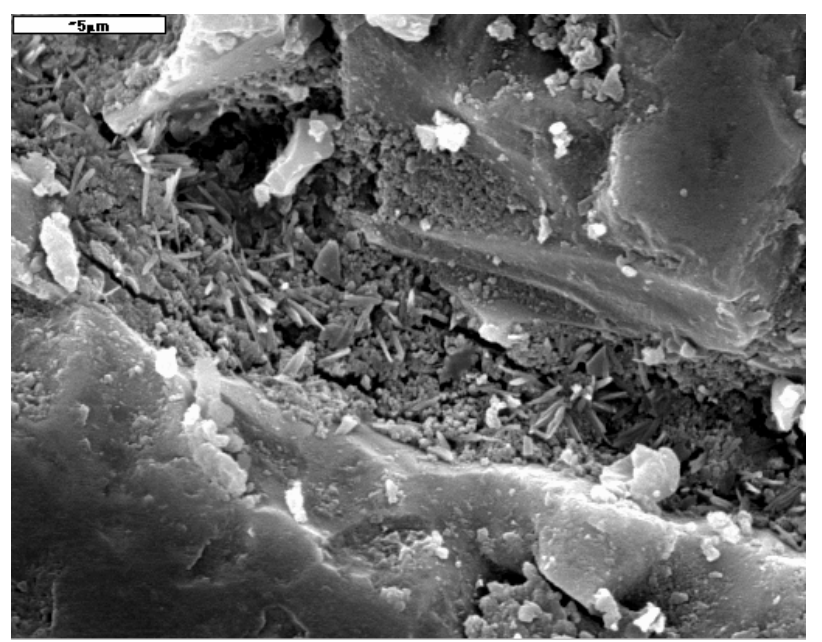

Fig 8. SEM image of silicate gel filling a crack in granite grain

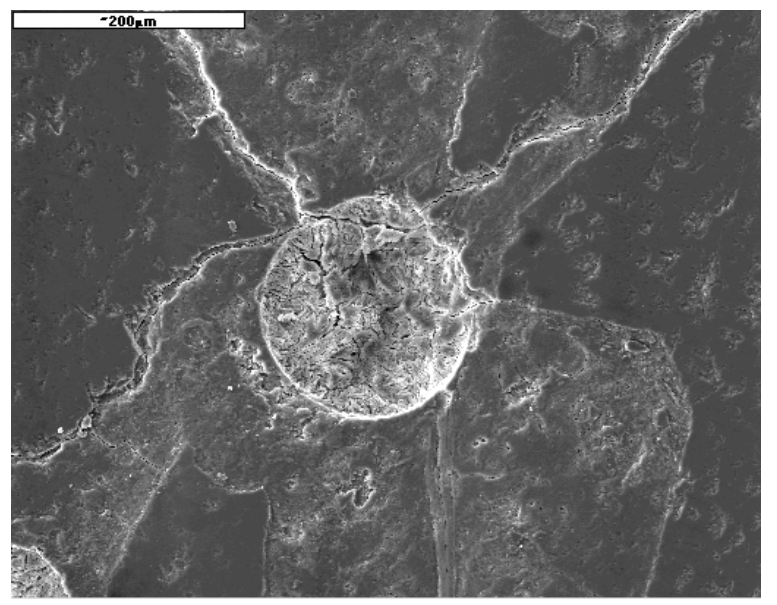

Fig 9. SEM image of alkali-silica gel at aggregate-paste interface and filling the pores in cement paste

Reaction products, ie the potassium-sodium-calcium silicates, with varied compositions, are observed both in the microcracks in reactive grains (Fig 8), in microcracks 
in cement paste and in air voids (Fig 9). Reaction products which occur in mortars or concretes have varied compositions. In case of testing a mortar with a reactive silica aggregate in a sodium hydroxide solution, reaction products are sodium-and-calcium silicates. However, the reaction product in high-alkali content cement mortars is the potassium-sodium-calcium silicate gel. Differences in reaction products morphology are also observed: their structures range from isotropic to cryptocrystalline. The reaction product, initially as the potassium-sodium silicate gel, binds calcium ions and in area situated away from the silica aggregate reactive grain surface it finally becomes a potassium-sodium-calcium silicate.

\section{Concluding remarks}

The results of chemical tests, which are conducted rapidly, do not always enable an assessment of aggregate behaviour in a high alkali concrete.

Expansion of the mortar bars with a rapid alkali reactive aggregate shows a good correlation with the aggregate performance in concrete built into structures, but a long time is needed to assess a given aggregate. In case of slow reactive alkali aggregates, even after 180 days, no expansion exceeding $0,1 \%$ is observed, and thus suggesting that the aggregate is alkali reactive, since in this case the alkalisilica reaction occurs very slowly, and its consequences can only become noticeable after several years [19].

Test results obtained through the accelerated method may be particularly useful for those aggregates which react slowly or produce a delayed expansion. However, these tests do not allow to assess a behaviour of the aggregate-binder combination under the conditions of the concrete performance. When an excessive expansion is observed, additional tests are recommended to confirm that the expansion is indeed caused by the alkali-silica reaction. Additional information can be provided by microstructure tests which enable the identification of the alkali reaction products, as well as other available methods allowing to estimate the aggregate behaviour through a record of concrete properties during field performance.

Summing up the standard aggregate testing methods in terms of aggregate alkali sensitivity, the most conclusive is the method of testing the deformation of the concrete bars, containing the aggregate tested and a higher alkali content cement. However, the recommended test duration of up to 180 days is too short, especially for reactivity determination of slow-reactive aggregates, such as granites or quartzites.

The appearance of cracks in hardened concrete may be related to a number of factors, such as drying shrinkage, thermal stresses, reinforcing steel corrosion, poor load-carrying capacity of the structure, structure overload, external load, chemical corrosion, and the like. Still, the occurrence of reaction products (gel) and microcracks is the major diagnostic symptom which confirms the occurrence of the alkali-aggregate reaction [20]. This reaction produces the swelling alkali silicate gel in aggregate grains and around them, which causes expansion, and as a result of the occurring strain, microcracks appear.
One of the many techniques for ASR determination in concrete is the scanning microscopy method combined with X-ray analysis within the microsurface, whose popularity is at present increasing. In the reactive grains of the aggregate which comes from various types of rocks, reaction products of varied composition can be observed, as well as various types of fractures, microcracks and disintegration of the aggregate grains. In case of slow reactive aggregates, a certain part of the reactive grains only can be capable of the alkali reaction, and the reaction is likely to begin at the output cracks, non-uniformities or grain combinations, which provide a route for the alkaline pore solution. The appearance of even a small amount of gel can cause expansion and aggregate cracking. Fine grains which rapidly react with the alkali (eg opal) produce occasional microcracks and the alkali silicate gel may be observed both inside and around the reactive grain.

Chemical test results have demonstrated that these tests are conducted rapidly, but they are not conclusive. Scale of the expansion in the mortar bars with a rapid alkali reactive aggregate shows a good correlation with the aggregate performance in concrete built into structures, but a longer time is needed to assess a given aggregate. In case of slow alkali reactive aggregates, even after 180 days, no expansion exceeding $0,1 \%$ is observed, and thus suggesting that the aggregate is alkali reactive. The accelerated method may be particularly useful for those aggregates which react slowly or produce a delayed expansion. However, these tests do not allow to assess a behaviour of the aggregate-binder combination under the conditions of the concrete performance.

\section{References}

1. FRENCH, W. J. The characterization of potentially reactive aggregates. In Poole, A. B. (Ed). Proc of 9th Int. Conf. Alkali-Aggregate Reaction in Concrete. Concrete Society Publication CS. 104, 1992, Vol 1, p. 338-346.

2. NIXON, P.; SIMSON, I. Testing aggregates for alkalireactivity. Report of RILEM TC 106, Materials and Structures, 2000, Vol 33, p. 88-93.

3. ASTM C 289-94. Standard Test Method for Potential Alkali Reactivity of Aggregates (Chemical Method).

4. ASTM C 227. Standard Test Method for Potential Alkali Reactivity of Cement-Aggregate Combinations. Annual Book of ASTM Standards, Section 4, Vol 04.02. (MortarBar Method), 1997.

5. ASTM C 1293. Standard Test Method for Concrete Aggregates by Determination of Length Change of Concrete Due to Alkali Silica Reaction.

6. ASTM C 1260. Standard Test Method for Potential Alkali Reactivity of Aggregates (Mortar-Bar Method), Annual Book of ASTM Standards, Section 4, Vol 04.02. Concrete and Aggregate, 1993.

7. DIAMOND, S. Chemistry and Other Characteristics of ASR Gels. In Berube, M. A. (Ed). Proc. of 11th Int. Conf. Alkali-Aggregate Reaction in Concrete. CRIB Publication, 2000, p. 31-40.

8. THOMSON, M. L.; GRATTAN-BELLEW, P. E.; WHITE, J. C. Application of microscopic and XRD techniques to investigate alkali-silica potential of rock and minerals. In Goudam G. R. (Ed.). Proc of 16th Intern. 
Conf. on Cement Microscopy. Intern. Cement Microstructure Development. George Allen \& Unwin Ltd, London, 1994, p. 247.

9. DOLAR-MANTUANI, L. M. M. Handbook of concrete aggregates: A petrographic and technological evaluation. Park Ridge, Noyes Publications, 1983, p. 345.

10. JENSEN, V. Present state of knowledge on Alkali Aggregate Reaction in Norway. Advanced Seminar on AlkaliAggregate Reaction. Queen Mary and Westfield College, University of London, 1990, p. 27.

11. LEE, Ch. Field AAR Inspection for the Four Harbours in Taiwan. In Proc of 11th ICAAR, Ed M. A. Berube, Quebec, 2000, p. 869-878.

12. FERITAG, S.; ST JOHN, D. A.; GOUGEL, R. ASTM C 1260 and the Alkali Reactivity of New Zealand Greywackes. In Proc of 11th ICAAR, Ed M. A. Berube, Quebec, 2000, p. 305-314.

13. OWSIAK, Z. Alkali aggregate reaction in concrete containing high alkali cement and granite aggregate. Cement and Concrete Research, 2004, Vol 34, p. 7-10.

14. THAUMA, W. E. et al. Alkali-Silica Reaction in Portland Cement Concrete-Testing Procedures and Mitigation
Methods. In Proc of 11th ICAAR, Ed. M. A. Berube, Quebec, 2000, p. 513-522.

15. OWSIAK, Z. Silica Aggregate-Alkali Reactions in Concrete. Polish Biuletyn Ceramiczny, Ceramika, 2002, Vol 72, 107 p.

16. KURDOWSKI, W. Cement Chemistry. Warszawa, PWN, 1991. $477 \mathrm{p}$.

17. PEUKERT, S.; OWSIAK, Z.; GARBACIK, A. Selected Aspects of Testing and Assessment of Alkali Silica Aggregate Reaction in Concrete. In Proc of XLIX Science Conf “Krynica-2003”, Vol II, p. 197-204.

18. HOBBS, D. W. Deleterious Alkali-Silica Reactivity in the Laboratory and under Field Conditions. Mag. Concr. Res., 1993, 45, (163), p. 103-112.

19. MULliCK, A. K.; WASON, R. C. Comparison of Different Expansion Tests to Assess Reactivity of Concrete. In Proc of 11th ICAAR, Ed, M. A. Berube, Quebec, 2000, p. 425-434.

20. OWSIAK, Z. Role of Calcium Hydroxide in Alkali-Silica Reaction. Cement-Wapno-Beton, 2003, 5, p. 259-263 (in Polish).

\section{ATRINKTŲJŲ BETONO UŽPILDŲ ŠARMINIO REAKTYVUMO TYRIMAI}

\section{Z. Owsiak}

Santrauka

Nagrinėjami specialiujų silicio užpildų reaktyvumo eksperimentinių tyrimų rezultatai. Analizuojama, kaip nustatomas greitasis ir lètasis šarmų reaktyvumas taikant ASTM metodiką. Silicio kiekis užpilde nustatytas natrio hidroksido tirpale. Plètimosi tyrimams buvo pagamintos skiedinio ir betono sijos su silicio turinčiais užpildais ir aukšto šarmingumo cementu. Skiedinio sijos buvo laikomos $80^{\circ} \mathrm{C}$ temperatūros natrio hidroksido tirpale. Pateiktos minètujų užpildų šarminių reakcijų produktų mikrostruktūros nuotraukos. Šarminio jautrumo atžvilgiu apibendrinant užpildų tyrimų standartiniais metodais rezultatus galima teigti, kad betono sijų deformacijoms didžiausią įtaką turi šarmų kiekis cemente. Tačiau 180 dienų bandymų trukmė per trumpa, kad būtų galima nustatyti lètai vykstantį užpildų reaktyvuma, ypač tokių užpildų kaip granitas ar kvarcas. Pagrindinis diagnostikos požymis, parodantis, kad vyksta užpildų šarminė reakcija, yra reakcijos produktų (šarminio silikato gelio) pasirodymas betone.

Reikšminiai žodžiai: šarminė silicio reakcija, bandymų metodas, SEM.

Zdzisława OWSIAK. Engineer Doctor (a Lecturer) at Dept of Civil and Environmental Engineering in Technical University in Kielce, Poland. Member of the Science Committee of the Polish Construction Engineer Association. Her research interests include concrete durability and in particular explaining the mechanism of concrete destruction caused by the reaction between aggregate with alkalies and the delayed ettringite formation. 